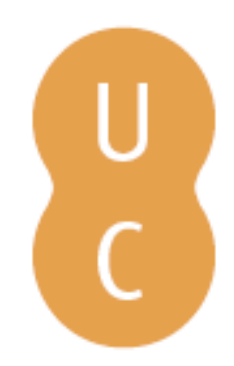

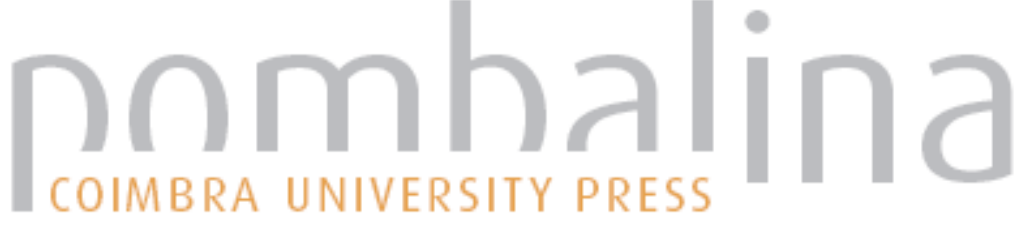

\section{Ash deposition during wildfire and its threat to water quality}

Autor(es): $\quad$ Santín, Cristina; Doerr, Stefan H.; Chafer, Chris J.

Publicado por: Imprensa da Universidade de Coimbra

URL

persistente:

URI:http://hdl.handle.net/10316.2/34160

DOI:

DOI:http://dx.doi.org/10.14195/978-989-26-0884-6_182

Accessed : $\quad$ 26-Apr-2023 12:04:09

A navegação consulta e descarregamento dos títulos inseridos nas Bibliotecas Digitais UC Digitalis, UC Pombalina e UC Impactum, pressupõem a aceitação plena e sem reservas dos Termos e Condições de Uso destas Bibliotecas Digitais, disponíveis em https://digitalis.uc.pt/pt-pt/termos.

Conforme exposto nos referidos Termos e Condições de Uso, o descarregamento de títulos de acesso restrito requer uma licença válida de autorização devendo o utilizador aceder ao(s) documento(s) a partir de um endereço de IP da instituição detentora da supramencionada licença.

Ao utilizador é apenas permitido o descarregamento para uso pessoal, pelo que o emprego do(s) título(s) descarregado(s) para outro fim, designadamente comercial, carece de autorização do respetivo autor ou editor da obra.

Na medida em que todas as obras da UC Digitalis se encontram protegidas pelo Código do Direito de Autor e Direitos Conexos e demais legislação aplicável, toda a cópia, parcial ou total, deste documento, nos casos em que é legalmente admitida, deverá conter ou fazer-se acompanhar por este aviso. 


\section{ADVANCES IN}

Forest Fire

\section{RESEARCH}

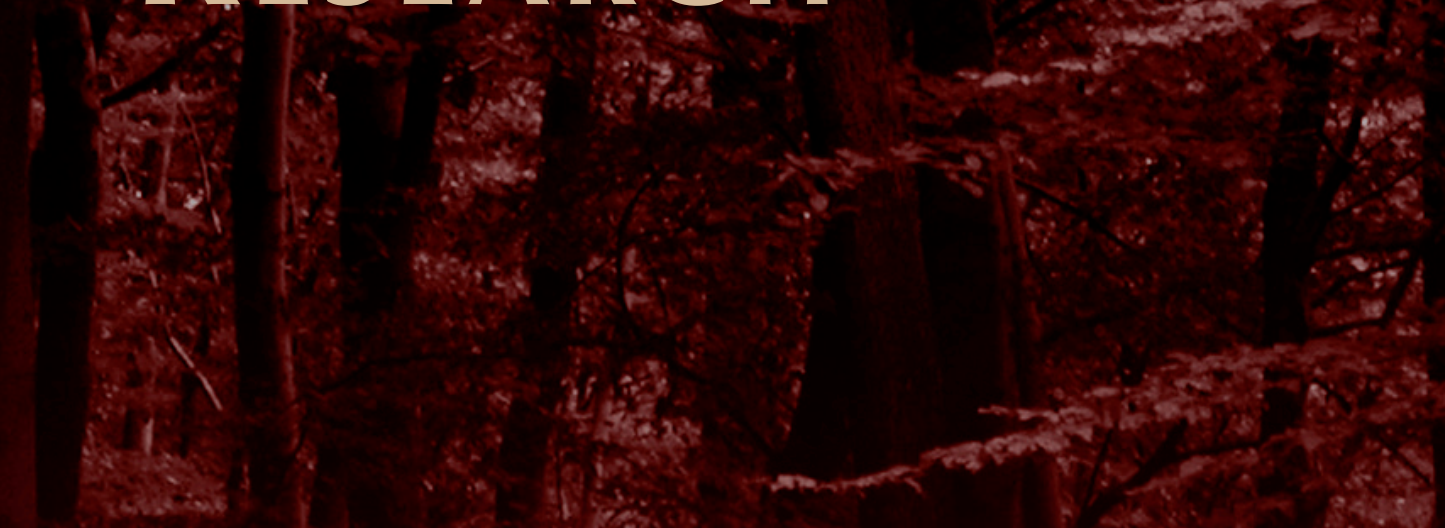

\section{DOMINGOS XAVIER VIEGAS}

\section{EDITOR}




\title{
Ash deposition during wildfire and its threat to water quality
}

\author{
Cristina Santín ${ }^{\text {a }}$, Stefan H. Doerr ${ }^{\mathrm{a}}$, Chris J. Chafer ${ }^{\mathrm{b}}$ \\ ${ }^{a}$ Department of Geography, College of Science, Swansea University, Singleton Park, Swansea SA2 \\ 8PP - United Kingdom; c.s.nuno@swansea.ac.uk; s.doerr@swansea.ac.uk \\ ${ }^{b}$ Sydney Catchment Authority, PO Box 323 Penrith, NSW, 2750 Australia; \\ chris.chafer@sca.nsw.gov.au
}

\begin{abstract}
The highly erodible ash material that covers the ground after fire is increasingly gaining attention as a potential major contributor to water contamination in fire-affected landscapes.

The recent and severe forest fires near Sydney (October 2013) provided an ideal opportunity to identity and quantify the potential main threats to water quality from pollutants present in the ash. These fires affected forests in the greater Sydney catchment, raising serious concerns about the risk of drinking water contamination from post-fire erosion.

An extensive sampling campaign (sampling points $=120$ ) was carried out in Jan. 2014 along a ridge with homogeneous vegetation and soils, but affected by a range of burn severities. Burn severity was classified based on the differenced Normalised Burn Ratio obtained from satellite imagery, validated by field observations and linked to estimates of fire intensity.

Three burn severities were sampled: extreme (>70,000 kW m-1); moderate (7000-500 kW m 1); and low (<500 $\mathrm{kW} \mathrm{m}-1)$. At each sampling point, the entire ash layer was collected from a square are of a specified size. The ash layer comprised the loose, charred and wettable material $(<1 \mathrm{~cm}$ size $)$ lying on top of uncharred waterrepellent mineral soil.

Total loads of ash increased substantially with burn severity with averages of 3516 and 6 t/ha for extreme, moderate and low severity sites, respectively. Notable differences exist in ash composition between fire severities, from comprising mainly charcoal and fine charred particles (derived largely from combustion of litter and vegetation) at low severity sites to a more mineral enriched composition (with substantial contribution from charred mineral soil) at extreme severity sites.

Results in bulk chemical composition of ash and main pollutants availability will be presented and discussed with special focus on potential implications for water quality impacts based on a series of post-fire rainfall and erosion scenarios.
\end{abstract}

Keywords: Australia, bushfire, fire severity, eucalypt forest, drinking water, pollutants.

\section{Introduction}

Wildfire enhances the risk of soil erosion and sediment transfer through the removal of vegetation and litter, and changes to soil wettability with associated contamination risks for surface water bodies. Most previous studies on post-fire erosion have focused on soil erosion and associated sediment transfer. The highly erodible ash material that covers the ground after fire and which can be rapidly mobilised and transferred into water bodies by water and wind erosion, however, has been largely overlooked to date. This ash, generated from combustion of vegetation, litter and surface soil, is increasingly gaining attention as a potential major contributor to post-fire water contamination (Bodi et al. 2014).

An extensive wildfire near Sydney (October 2013) provided us with an ideal opportunity to determine the quantities of ash produced during wildfire in relation to burn severity and to identity and quantify the main threats to water quality from contaminants contained in the ash. The fire affected parts of the Nepean catchment, which contributes to the greater Sydney water supply system, raising serious concerns about the risk of water contamination from post-fire erosion. 


\section{Methods}

In October 2013, severe wildfires burnt 10,000 ha of dry sclerophyl eucalypt forest near Sydney (NSW, Australia). Sampling was carried along at a ridge in the Nepean catchment with homogeneous vegetation species composition, fuel load and soil characteristics, but with a range of burn severities, resulting from wind-driven differences in fire behaviour. Burn severity was determined using the differenced normalised burn ratio (dNBR) obtained from satellite images immediately before (1 day) and after ( 1 week) the fire, supported by on site determination of fuel consumption completeness and linked to estimates of fire intensity. Between the fire and the sampling campaign (early January 2014), rainfall was very limited so that there had been no significant redistribution of material by water erosion.

Three burn severities were sampled: i) extreme $\left(>70,000 \mathrm{~kW} \mathrm{~m}^{-1}\right)$, ii) moderate $\left(7000-500 \mathrm{~kW} \mathrm{~m}^{-1}\right)$, and iii) low $\left(<500 \mathrm{~kW} \mathrm{~m}^{-1}\right)$. For each burn severity, three replicate sites were sampled with 30 sampling points each. At each sampling point, a square of known size was sampled by careful brushing together and collecting the entire ash layer. The ash layer comprised the loose, charred and wettable material $(<1 \mathrm{~cm}$ size) material lying on top of uncharred water-repellent mineral soil. It included residues from the burning of aboveground vegetation and litter, as well as the completely-charred and structureless surface mineral soil. Litter and soil was also samplied at a long-unburned control site on the same ridge.

All samples being analysed for basic parameters ( $\mathrm{pH}, \mathrm{CEC}$, and total carbon, phosphorous and nitrogen concentrations) as well as total concentrations of trace elements at the time of writing. In addition, leaching tests (Hageman et al. 2008) will be also performed on selected representative samples to assess biochemical availability of toxic elements (metals and metalloids) and eutrophication agents (nutrients).

\section{Results}

Irrespective of burn severity the ash layer was consistently wettable and dark in colour whereas the underlying uncharred soil was highly water repellent and lighter in colour. However, notable differences exist in ash composition between the different fire severities, from comprising mainly charcoal and fine charred particles (derived largely from combustion of litter and understory vegetation) at low severity sites to a more mineral enriched composition (probably with substantial contribution from charred mineral soil) at extreme severity sites.

Total loads of ash increased substantially with burn severity with averages of 35 ( \pm 2.0 Standard Error of Mean), $16( \pm 0.9 \mathrm{SEM})$ and $6 \mathrm{t} / \mathrm{ha}( \pm 0.7 \mathrm{SEM})$ for extreme, moderate and low severity sites, respectively. Ash bulk density also increased with burn severity with values of 58.9 (STDEV 6.4), 53.7 (STDEV 14.9) and $34.5 \mathrm{~g} \mathrm{~cm}^{3}$ (STDEV 16.4) for extreme, moderate and low severity sites, respectively, which supports the increasing contribution from charred mineral soil with burn severity. Results regarding bulk chemical composition of ash and the availability of main pollutants will be presented and discussed with special focus on potential implications for water quality impacts based on a series of post-fire rainfall and erosion scenarios. 


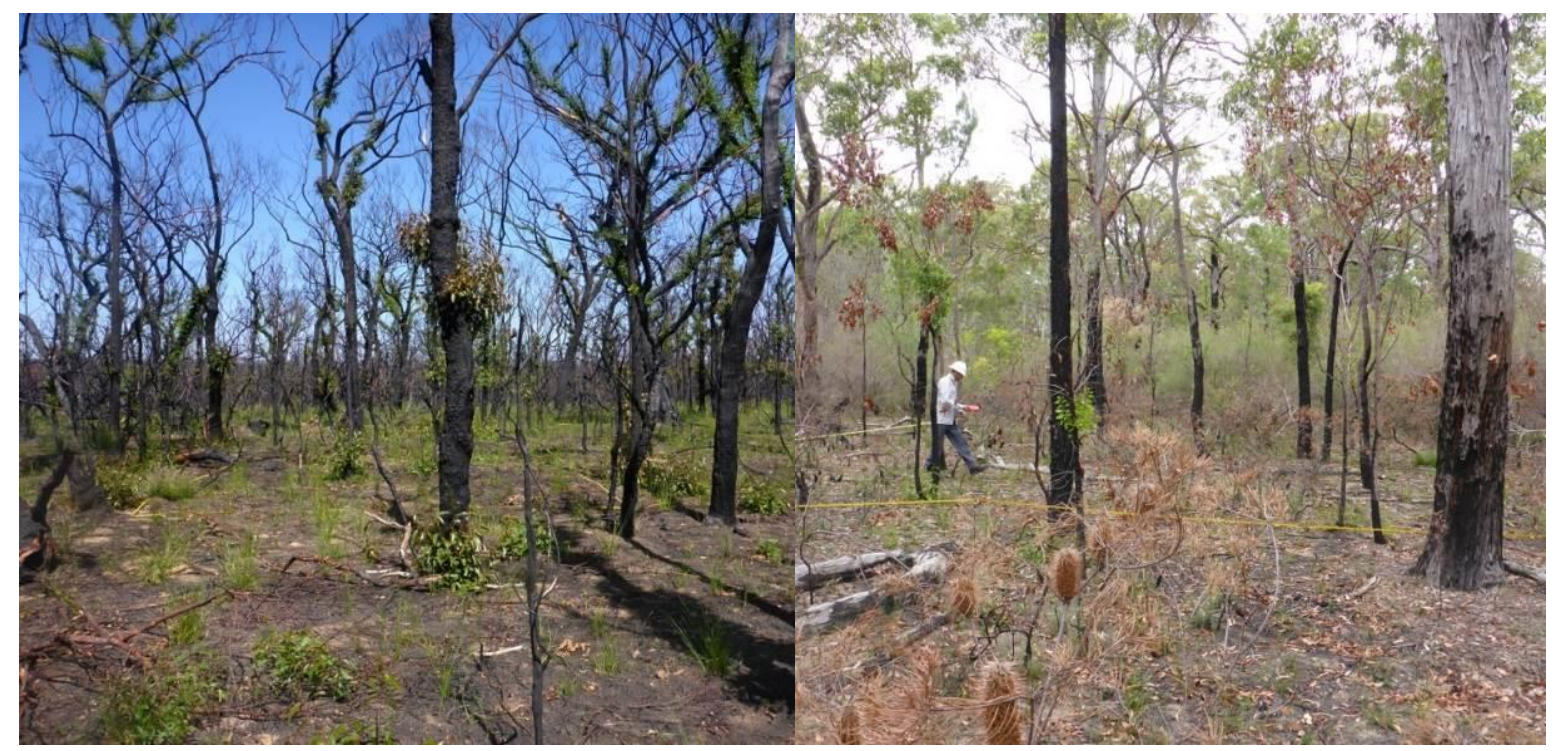

Figure 1. Extreme severity (left) and Low Severity (right) sampling sites 3 months after fire.

\section{References}

Bodí M.B., Martin D., Balfour V.N., Santín C., Doerr S.H., Pereira P., Mataix-Solera J., Cerdà A. 2014. Wildland fire ash: production, composition and eco-hydro-geomorphic effects. Earth-Science Reviews 130:103-127.

Hageman, P.L., Plumlee, G.S., Martin, D.A., Hoefen, T.M., Adams, M., Lamothe, P.J., Todorov, T., Anthony, M.W., Leachate Geochemical Results for Ash Samples from the June 2007 Angora Wildfire near Lake Tahoe in Northern California, 2008: U.S. Geological Survey Open-File Report 2008-1170. http://pubs.usgs.gov/of/2008/1170/ 